f. med. Genet. (1969). 6, 413 .

\title{
A Liveborn Infant with Complete Triploidy (69,XXX)
}

\author{
L. J. BUTLER, C. CHANTLER, N. E. FRANCE, and C. G. KEITH \\ From Queen Elizabeth Hospital for Children, Hackney Road, London E.2
}

The special report of the World Health Organization (1966), summarizing the results of chromosome studies in spontaneous abortion, revealed that $17 \%$ of those with an abnormal karyotype were triploids. More recently Edwards et al. (1967), in reporting two further abortions with triploidy, showed that, with an abortion rate of $20 \%$ and using Carr's data (Carr, 1965), the survival rate of triploid embryos was much less than $1 \%$. Consequently there are few reports of liveborn infants with this chromosome complement and, with two exceptions described by Bernard et al. (1967) and by Edwards et al. (1967), all have been mosaics (Böök and Santesson, 1960, 1961; Ellis et al., 1963; Ferrier et al., 1964; Lejeune et al., 1967; Sacrez et al., 1967; Schmid and Vischer, 1967).

\section{Case Report}

This female child was the result of the first pregnancy of a 21-year-old, group $\mathrm{O} \mathrm{Rh}$ negative, $\mathrm{Hb} \mathrm{S} / \mathrm{A}$, West Indian woman whose husband was aged 24 years. No Rhesus antibodies were detected during pregnancy which was uneventful until the onset of labour at 35 weeks' gestation. A small antepartum haemorrhage was noted, but labour progressed despite the administration

Received June 30, 1969. of isoxsuprine hydrochloride (Duvadilan) and there was no evidence of foetal distress. Delivery was spontaneous by the vertex at 35 weeks. The birthweight of $1825 \mathrm{~g}$. was below the 10th percentile for the period of gestation -crown-rump length was $29 \mathrm{~cm}$., and crown-heel length $41.5 \mathrm{~cm}$.

At birth she was severely collapsed with an Apgar score of 1 at one minute. Spontaneous but irregular and grunting respirations were established only after 45 minutes and there was marked subcostal recession. Cynanosis was absent while $56 \%$ oxygen was being administered.

The occipito-frontal circumference was $30.5 \mathrm{~cm}$. (25th percentile), and the anterior and posterior fontanelles measured $3 \times 2.5 \mathrm{~cm}$. and $7 \times 3 \mathrm{~cm}$., respectively. The face was flat with obvious hypertelorism (interpupillary distance $3.5 \mathrm{~cm}$.). The eyes had small oval corneae and infero-medial colobomata of the irides. The upper lip was long, but the mouth and palate were normal. The ears were poorly convoluted and low set, but the external auditory meati were normal. The neck was slightly short, but there were no external abnormalities of the thorax and abdomen. The spleen was palpable $3 \mathrm{~cm}$. below the left costal margin.

Both arms were similar, each having two creases at the elbow and one at the mid-forearm. Single palmar creases were present and the distal flexion creases were absent on digits II-IV on each hand. Three creases were present on the Vth digits, but the two proximal creases were very
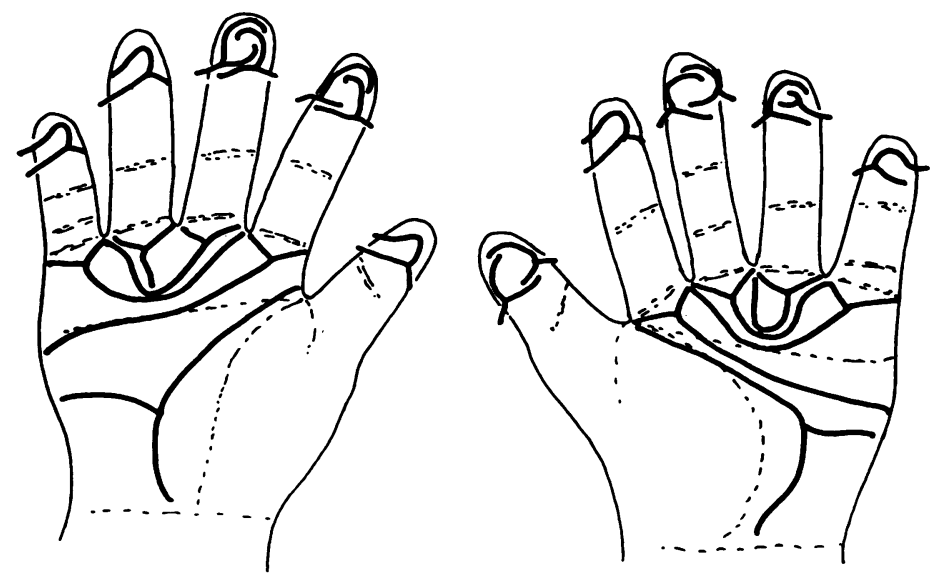

FIG. 1. Diagram showing dermatoglyphic features (solid lines) and flexion creases (dotted lines) of the hands. 
close together. The thumbs were proximally situated. The nails were well developed and hyperconvex. The dermatoglyphic features (Fig. 1) were unusual with 5/10 digital whorls, bilateral $t$ ' triradii, a ' $c$ ' loop in the third interdigital space on the right (vestigial on the left), and absent thenar and hypothenar patterns. The halluci were short, and there was a wide first interdigital space on the left. The IInd and IIIrd toes were long with bulbous ends and the left Vth toe was very small. The IInd toe was overriding the IIIrd on the right foot. Whorls were present on toes I-III bilaterally and tibial loops were present on all others. The hallucal areas were patternless.

At 6 hours the blood sugar was below $20 \mathrm{mg} . / 100 \mathrm{ml}$. by dextrostix (Chantler, Baum, and Norman, 1967); she was therefore given $2 \mathrm{~g}$. dextrose with $4 \mathrm{mEq}$ sodium bicarbonate intravenously. After transfer to this hospital, treatment of the hypoglycaemia and respiratory distress syndrome were continued with intravenous $10 \%$ dextrose and sodium bicarbonate solution. At this time no primitive reflexes or motor responses could be elicited and she was hypotonic. An apical systolic murmur was heard but the heart sounds were normal.

The cord blood was group A Rhesus positive, $\mathrm{Hb}$ $17 \cdot 2 \mathrm{~g} . / 100 \mathrm{ml}$., and the direct Coombs' test was positive. The serum bilirubin at 12 hours of age was $10.3 \mathrm{mg}$./ $100 \mathrm{ml}$

The infant's condition rapidly deteriorated and she lapsed into congestive cardiac failure. The capillary $p \mathrm{H}$ at 12 hours was $7 \cdot 08$, and despite rapid digitalization, the cardiac failure became more severe and she died 23 hours after birth.

The mother's blood was further examined 22 weeks post partum. This study was kindly undertaken by Dr. K. L. G. Goldsmith at the Medical Research Council Group Reference Laboratory. He reported that 'the serum contained no $\mathrm{Rh}$-antibodies at $37^{\circ} \mathrm{C}$ in saline, albumin with Löw's cysteine-activated papain, ficintreated cells and the anti-human-globulin technique. The presence of immune anti-A was demonstrated by partial inhibition of group A secretor saliva. The titre of anti-A with A1 cells in neutralized serum was 32 and a positive reaction was obtained with it by the antihuman-globulin technique using a potent anti-gamma-G. At $37^{\circ} \mathrm{C}$ some haemolysis of Al cells was observed.'

\section{Necropsy Findings}

The right side of the heart showed considerable dilatation associated with a large ostium secundum defect measuring $1.2 \times 0.9 \mathrm{~cm}$. and a small, high ventricular septal defect $0.4 \mathrm{~cm}$. diameter. The pulmonary and aortic valves were bicuspid. The great vessels were normal, and both umbilical arteries were present.

The right kidney $(8 \mathrm{~g}$.) was immature and moderately hydronephrotic and its ureter was dilated to $0.4 \mathrm{~cm}$. diameter but was not tortuous. There was no obvious organic obstruction to the flow of urine. The left kidney (1 g.) consisted of loose connective tissue in which were isolated glomeruli and tubules, dysplastic tubules, and occasional small groups of normal glomeruli and tubules. Cysts up to $0.3 \mathrm{~cm}$. diameter, lined by flat or cuboidal epithelium, were scattered throughout. The upper half of the left ureter was represented by a thin, fibrous band, but the lower half was normal. Bladder and uterus were normal but both ovaries were hypoplastic and consisted of small masses of cells resembling granulosa cells, occasionally including ova, and separated by thin bands of normal-looking stroma. Only a single typical primordial follicle was observed. There was a ? universal mesentery but the gut was normally rotated.

The adrenal glands together weighed only $0.51 \mathrm{~g}$.

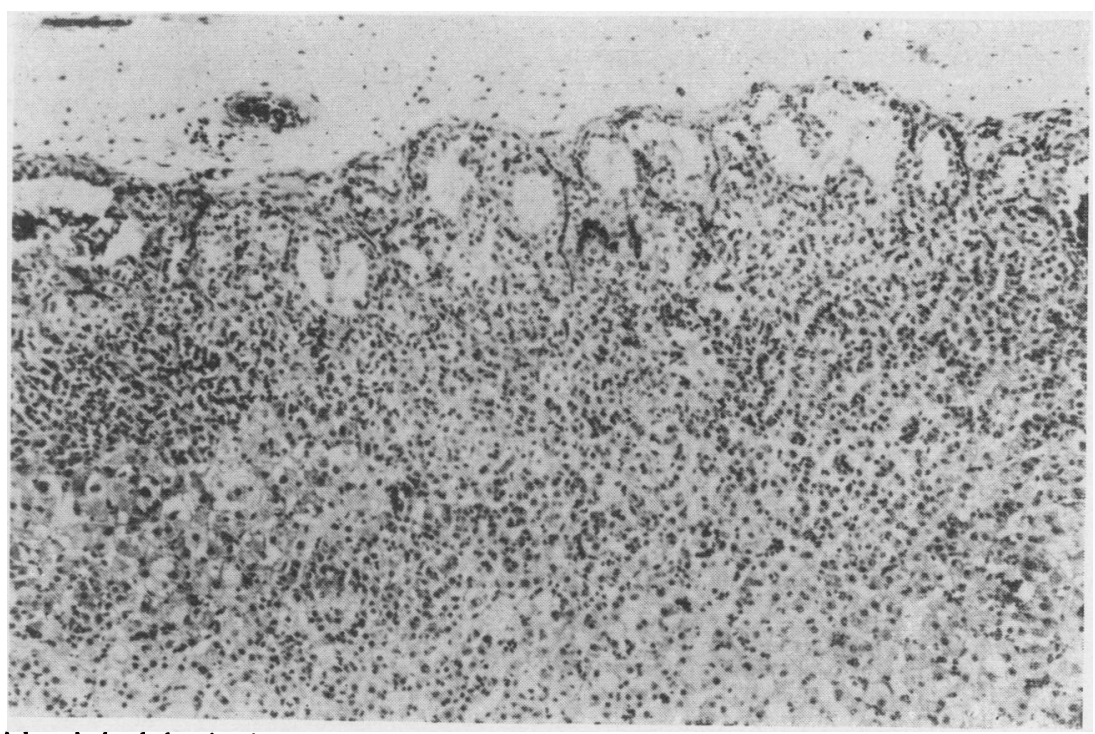

FI's. 2. Adrenal gland showing immaturity of the definitive cortex and hypoplasia of the foetal cortex. (H. and E. $\times 75$.) 


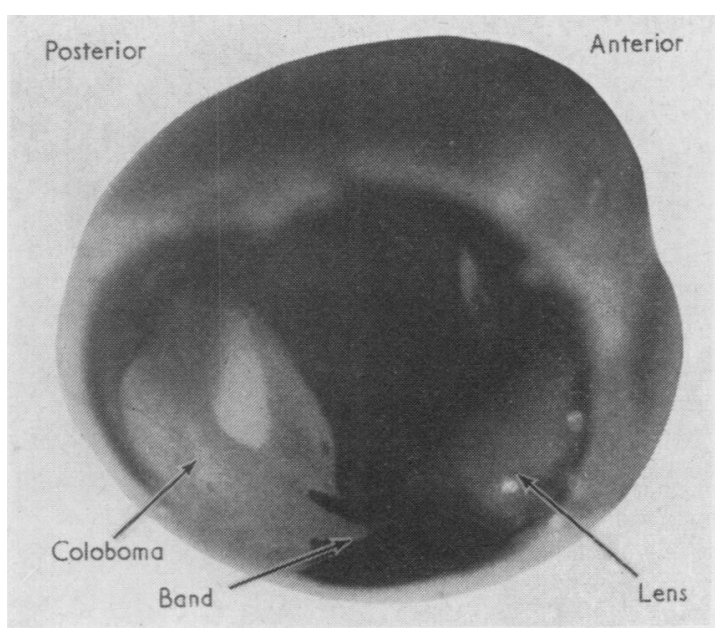

FIG. 3. Right eye showing a coloboma of the choroid involving the optic disc with a band of tissue stretching to the inferior pole of the lens. $(\times 4$.

(normal 5 g.). The thin, definitive cortex was composed or irregularly arranged cells which, in the subcapsular region, included large spaces often containing blood; it had the over-all appearance of gross immaturity. The foetal cortex was obviously hypoplastic (Fig. 2). The pituitary $(0.04 \mathrm{~g}$.) was small but histologically normal. The brain (200 g., normal 255 g.) appeared normal.

The spleen (12 g., normal $9 \mathrm{~g}$.) was soft and congested and the liver (192 g., normal $76 \mathrm{~g}$.) showed foci of haemopoiesis consistent with the maturity of the infant. In spite of its size (935 g., normal about $450 \mathrm{~g}$.), the placenta showed no evidence of erythroblastotic or hydatidiform change, and was histologically consistent with the period of gestation though there were scattered small foci of calcification throughout its substance.

All diameters of the right eye were approximately
$16 \mathrm{~mm}$. The cornea was oval and measured $8 \mathrm{~mm}$. vertically and $5.5 \mathrm{~mm}$. horizontally. There was a coloboma of the infero-medial segment of the iris. Vertical section in the lateral half revealed a coloboma of the choroid involving the optic disc, but not reaching the ciliary body, except at one point where a band of tissue stretched to the inferior pole of the lens (Fig. 3). Microscopically the cornea and sclera appeared normal. One iris leaf was absent and the angle of the anterior chamber was filled by loose connective tissue. The trabeculae were poorly formed, the canal of Schlemm was present, and the iris stroma appeared normal. The anterior layer of the iris epithelium was pigmented, and had proliferated into the stroma here and there while elsewhere it enclosed large vascular spaces. The posterior epithelial layer was unpigmented in the proximal half. At the other side of the anterior chamber there was a small stump of iris, and a few trabeculae were present, but no canal of Schlemm was seen. The lens was vacuolated posteriorly, and there was some vascular tissue on its posterior surface. The choroid was absent at the site of the coloboma. The retina was normal, except over the colobomatous area where it consisted mainly of loose glial tissue containing some rosettes (Fig. 4), but in some parts it was missing. On the side of the coloboma the ciliary body was flattened, and there were many short ciliary processes. On the other side, the ciliary body was well formed and was covered by a continuation of the retina consisting of several poorly differentiated layers which were reduced to a single layer anteriorly (Fig. 5). The coloboma involved part of the optic nerve which otherwise appeared normal.

The left eye was substantially similar.

All other organs were normal.

\section{Cytogenetic Studies}

Chromosome preparations were obtained from microcultures of peripheral blood and from cultures of skin obtained post mortem. Apart from a few cells with hypomodal counts considered to be broken during

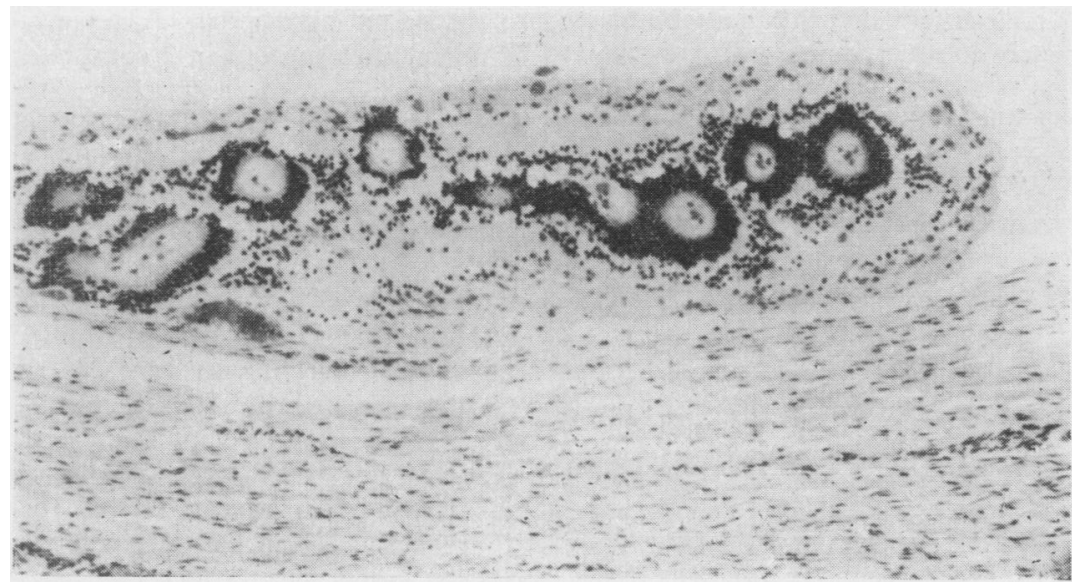

FIg. 4. Edge of R. coloboma with loose glial tissue containing rosettes. (H. and E. $\times 75$.) 


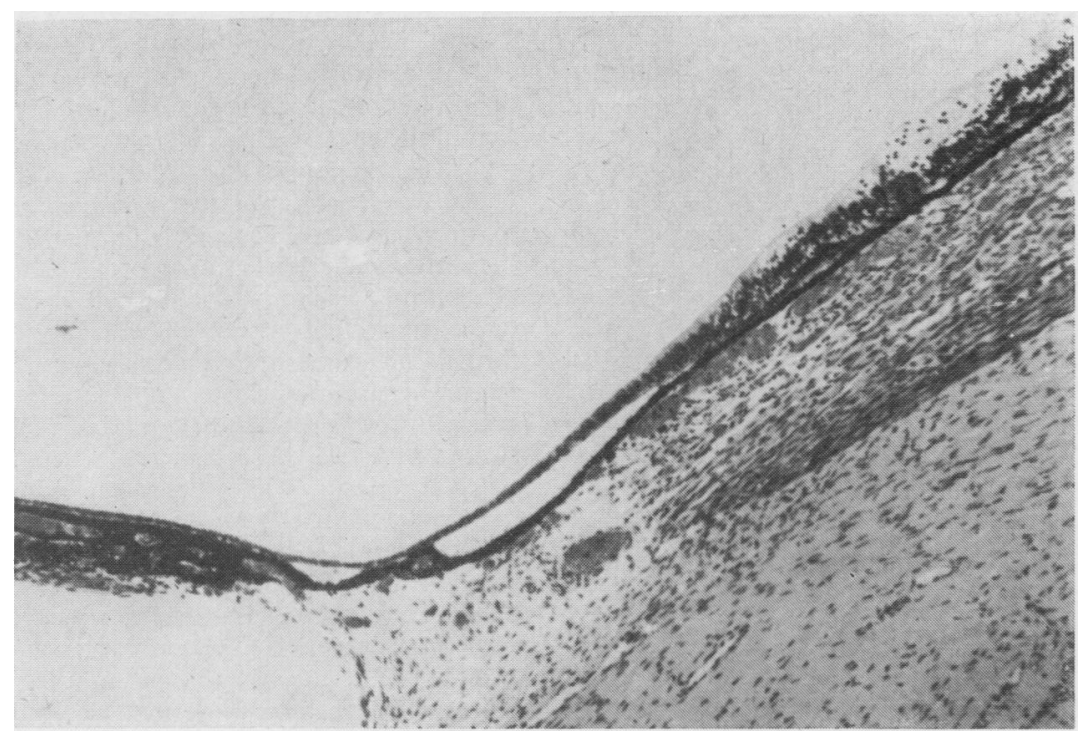

FIG. 5. Right eye showing ciliary body on the side opposite to the coloboma covered by attenuated retina. (H. and E. $\times 75$.)

preparation, in both tissues the modal number was 69 with no evidence of mosaicism (Table I). Karyotype analysis of several cells showed typical triplody with XXX sex chromosomes (Fig. 6a and b).

Nuclei of cultured fibroblasts were examined for sex chromatin, and $67(32.5 \%)$ had a single chromatin body while $134(65 \%)$ were chromatin negative. Only 5 nuclei $(2.5 \%)$ had two chromatin bodies (Fig. 7) and, considering their size, 2 of these were probably hexaploid (6n).

Photographs were taken to record the fibroblast nuclei in randomly selected fields using a $\times 40$ objective. The outlines of all nuclei in each field not showing gross distortion were drawn on to squared paper from the projected image of the negative at a final magnification of $\times 1400$. The areas were estimated in arbitrary units, and Fig. 8 shows their distribution with a mean nuclear area of approximately 26 square units. The histogram shows essentially a single peak thus indicating the presence of a single population of cells. Nuclei from normal female $(46, \mathrm{XX})$ fibroblast cultures, matched for culture time, division rate, and processing technique, were examined as a control. The distribution of nuclear

\section{TABLE I}

DISTRIBUTION OF CHROMOSOME COUNTS

\begin{tabular}{c|c|c|c|c|c|c|c}
\hline Tissue & \multicolumn{3}{|c|}{ Chromosome Count } & \multirow{2}{*}{ Karyotype } \\
\cline { 2 - 5 } & $<68$ & 68 & 69 & 70 & $>70$ & \\
\hline $\begin{array}{c}\text { Blood } \\
\text { Skin }\end{array}$ & 5 & 0 & 26 & 0 & 0 & \multirow{2}{*}{$69, \mathrm{XXX}$} \\
\hline Total & 9 & 0 & 54 & 0 & 0 & \\
\hline
\end{tabular}

areas is also shown in Fig. 8 , and the mean area is approximately $16 \mathrm{sq}$. units. The triploid nuclei are therefore approximately $60 \%$ larger than the control nuclei, the deviation from the expected difference being accoun 8 ted for by the greater proportion of polypoid nuclei in the triploid series.

The karyotypes of both parents were investigated using peripheral blood cultures and these were normal.

\section{Discussion}

This infant is the first complete triploid with 69 , XXX to survive to be born alive after 28 weeks' gestation, the only other recorded examples being spontaneous abortions. A review of the clinical abnormalities present in 3 complete triploids and 6 diploid/triploid mosaics shows that they share relatively few malformations (Table II). The most distinctive defects were syndactyly of hands and/or feet and eye defects. The ocular changes in our child were similar to those reported in some cases of the trisomy-13 syndrome (Snodgrass et al., 1966; Keith, 1966). Two of the mosaics showed body asymmetry and all were mentally retarded. Detailed information was available on the dermatoglyphs of six individuals including two complete triploids. Both of the latter had some unusual features but there were few in common. Apart from fused $a-b$ triradii related to the syndactyly there was an unusual frequency and situation of radial loops and whorls in the $69, \mathrm{XXY}$ male 


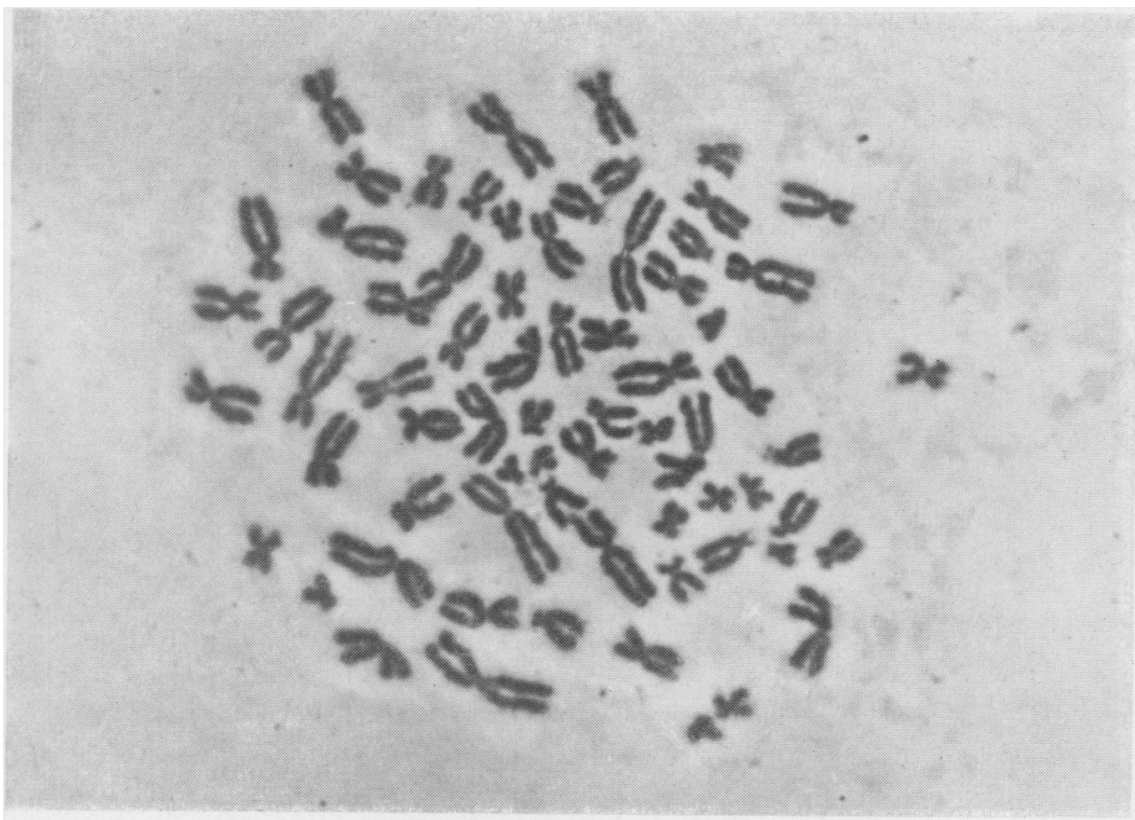

(a)
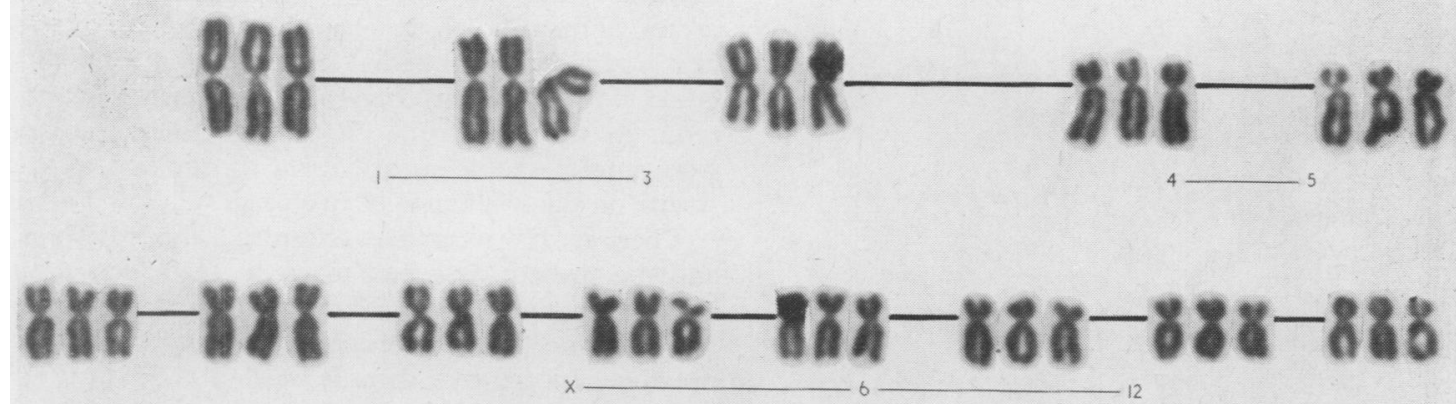

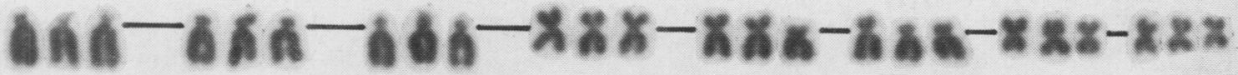
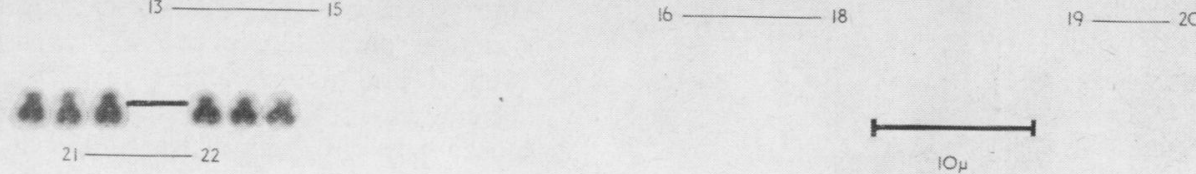

(b) Fig. 6. (a) A peripheral blood leucocyte in metaphase showing 69 chromosomes. (b) Karyotype of a skin fibroblast showing typical
triploidy $(69, \mathrm{XXX})$. 


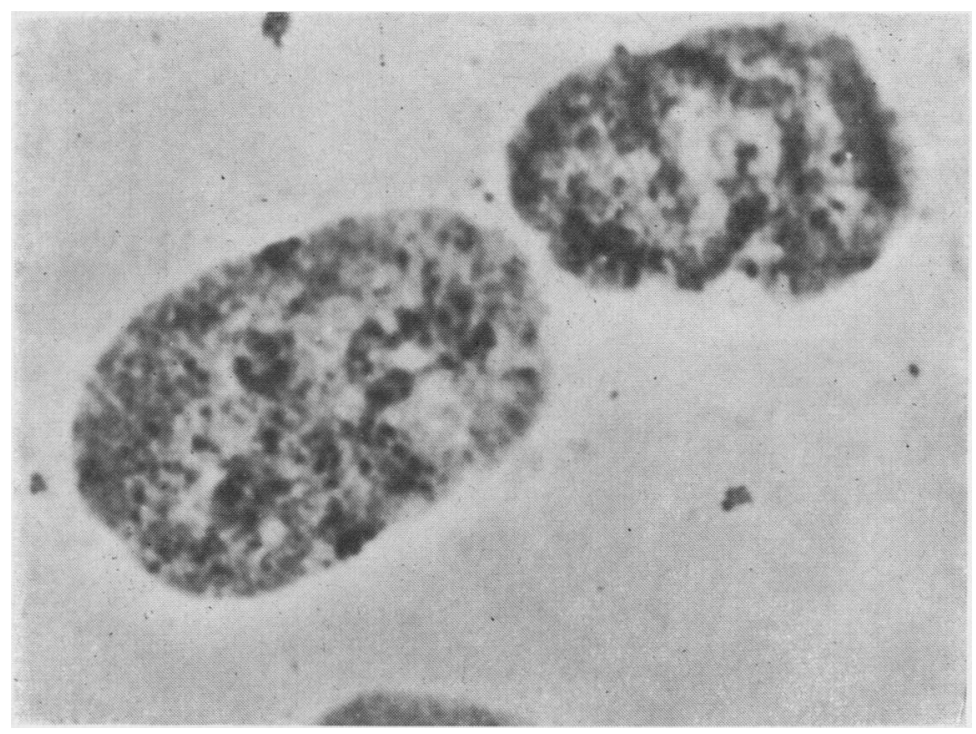

FIG. 7. A fibroblast nucleus containing two sex chromatin bodies.

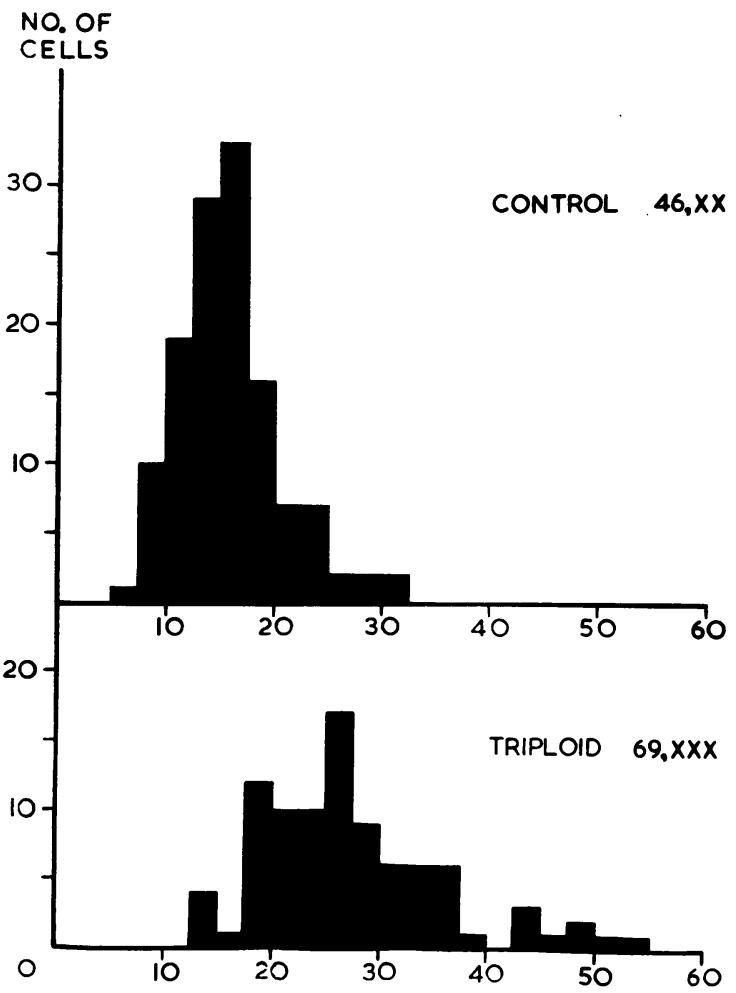

FIG. 8. Diagram showing the distributions of nuclear areas of normal female $(46, \mathrm{XX})$ and triploid $(69, \mathrm{XXX})$ fibroblasts. described by Edwards et al. (1967). The female infant in this report had somewhat distal $t$ triradii and twice as many whorls as the population mean of $2 \cdot 5$. Penrose (1968) has made a detailed study of five of the cases mentioned, and has shown that they have nearly twice as many radial loops as a control population with a higher than normal number of triradii on the ulnar side $(R+W)$. Other features were unremarkable except for a thenar exit of the A-line on the left hands of two cases.

There are few references to internal abnormalities, and the present case had many more defects than any others described to date. Of particular note was the presence of adrenal hypoplasia, a feature previously noted by Edwards et al. (1967).

The over-all number and severity of congenital malformations in the surviving triploids and welldifferentiated embryos is therefore small. On the other hand a large number of those which abort spontaneously either do not contain a recognizable embryo or contain a severely malformed one, a situation paralleled in the 45,X syndrome (Carr, 1965). The abnormalities involving the genital system are of special interest. Three of the five mosaic triploids with at least one cell line containing a $\mathrm{Y}$ chromosome showed some degree of intersexuality, and both complete XXY triploids were intersexual but with testes showing marked Leydig cell hyperplasia (see Table II). Patients with 47,XXY Klinefelter's syndrome on the other hand 
TABLE II

CONGENITAL ANOMALIES IN PATIENTS WITH COMPLETE AND MOSAIC TRIPLOIDY

\begin{tabular}{|c|c|c|c|c|c|c|c|c|c|c|}
\hline Reference & $\begin{array}{c}\text { Böök and } \\
\text { Santesson } \\
(1960)\end{array}$ & $\begin{array}{c}\text { Ellis } \\
\text { et al. } \\
(1963)\end{array}$ & $\begin{array}{c}\text { Ferrier } \\
\text { et al. } \\
(1964)\end{array}$ & $\left|\begin{array}{c}\text { Bernard } \\
e t \text { al. } \\
(1967)\end{array}\right|$ & $\mid \begin{array}{c}\text { Edwards } \\
\text { et al. } \\
\text { (1967) }\end{array}$ & $\begin{array}{c}\text { Lejeune } \\
\text { et al. } \\
(1967)\end{array}$ & $\begin{array}{l}\text { Sacrezz } \\
\text { et al. } \\
(1967)\end{array}$ & $\begin{array}{c}\text { Schmid and } \\
\text { Vischer } \\
\text { (1967) }\end{array}$ & $\begin{array}{c}\text { Present } \\
\text { Case }\end{array}$ & $\begin{array}{c}\text { Total } \\
\text { Ano- } \\
\text { malies }\end{array}$ \\
\hline $\begin{array}{l}\text { Phenotype } \\
\text { Gestation (wk.) } \\
\text { Birthweight (kg.) } \\
\text { Placenta weight (kg.) } \\
\text { Age examined } \\
\text { Maternal age (yr.) } \\
\text { Paternal age (yr.) } \\
\text { Number of sibs } \\
\text { Number of abortions } \\
\text { Age at death } \\
\text { Karyotype } \\
\text { Sex chromatin }\end{array}$ & $\begin{array}{c}1 \text { yr. } \\
30 \\
29 \\
1 \\
? \\
\text { Alive } \\
46, \mathrm{XY} / \\
69, \mathrm{XXY} \\
?\end{array}$ & $\mid \begin{array}{c}6 \text { yr. } \\
23 \\
39 \\
2 \\
? \\
\text { Alive } \\
46, \mathrm{XX} / \\
69, \mathrm{XXX} \\
?\end{array}$ & \begin{tabular}{|c|}
$M$ \\
$?$ \\
$1 \cdot 85$ \\
$?$ \\
$10 \mathrm{yr}$. \\
25 \\
31 \\
3 \\
$?$ \\
Alive \\
$46, \mathrm{XY} /$ \\
$69, \mathrm{XXY}$ \\
\end{tabular} & $\mid \begin{array}{c}\text { Newborn } \\
27 \\
38 \\
1 \\
? \\
15 \mathrm{hr} . \\
69, \mathrm{XXY} \\
?\end{array}$ & \begin{tabular}{|c|} 
Ambigu- \\
ous \\
32 \\
$?$ \\
$2 \times$ \\
normal \\
size \\
Newborn \\
30 \\
37 \\
3 \\
3 \\
$7 \mathrm{hr}$ \\
$69, \mathrm{XXY}$ \\
-
\end{tabular} & \begin{tabular}{|c|} 
Ambigu- \\
ous \\
40 \\
3.75 \\
1.50 \\
\\
1 mth. \\
21 \\
$?$ \\
0 \\
0 \\
Alive \\
$46, X X /$ \\
$69, \mathrm{XXY}$ \\
+
\end{tabular} & \begin{tabular}{|c|}
$F$ \\
36 \\
$1 \cdot 00$ \\
$?$ \\
\\
Newborn \\
$?$ \\
$?$ \\
0 \\
$01 \mathrm{hr}$. \\
$46, \mathbf{X Y} /$ \\
$69, \mathbf{X X Y}$ \\
+
\end{tabular} & \begin{tabular}{|c|}
$M$ \\
43 \\
1.90 \\
$?$ \\
\\
11 mth. \\
25 \\
23 \\
1 \\
0 \\
Alive \\
$48, X X Y Y /$ \\
$71, X X X Y Y$ \\
+
\end{tabular} & \begin{tabular}{|c|}
$\mathrm{F}$ \\
35 \\
$1 \cdot 83$ \\
$1 \cdot 02$ \\
\\
Newborn \\
21 \\
24 \\
0 \\
0 \\
$23 \mathrm{hr}$. \\
$69, \mathrm{XXX}$ \\
+
\end{tabular} & \\
\hline $\begin{array}{l}\text { External abnormalities } \\
\text { Craniofacial } \\
\text { Abnormal shape of skull } \\
\text { Abnormal palpebral fissures } \\
\text { Hypertelorism } \\
\text { Epicanthic folds } \\
\text { Microphthalmia } \\
\text { Colobomata } \\
\text { Low-set ears } \\
\text { Malformed ears } \\
\text { Micrognathia } \\
\text { Long upper lip } \\
\text { High arched palate } \\
\text { Cleft palate } \\
\text { Irregular gum margins } \\
\text { Thorax and abdomen } \\
\text { Wide set, aplastic nipples } \\
\text { Hypolastic genitalia } \\
\text { Hypospadias } \\
\text { Bifid scrotum } \\
\text { Cryptorchidism } \\
\text { Limbs } \\
\text { Flexion deformity of fingers } \\
\text { Syndactyly of hands } \\
\text { Hyperconvex nails } \\
\text { Single palmar creases } \\
\text { Abnormal dermatoglyphs } \\
\text { Talipes, equinovarus } \\
\text { Syndactyly of feet } \\
\text { Wide 1st interdigital space of } \\
\text { feet } \\
\text { Overriding toes } \\
\text { Hypoplastic toes } \\
\end{array}$ & + & + & $\begin{array}{l}+ \\
+\end{array}$ & $\begin{array}{l}+ \\
+ \\
+ \\
+ \\
+\end{array}$ & $\begin{array}{l}+ \\
+ \\
+ \\
+ \\
+ \\
+\end{array}$ & $\begin{array}{l}+ \\
+ \\
+ \\
+ \\
+ \\
+ \\
+\end{array}$ & $\begin{array}{l}+ \\
+ \\
+ \\
+ \\
+ \\
+ \\
+ \\
+ \\
+\end{array}$ & $\begin{array}{l}+ \\
+ \\
+ \\
+ \\
+ \\
+\end{array}$ & $\begin{array}{l}z \\
\pm \\
\pm \\
+ \\
+ \\
\pm \\
\pm \\
\pm \\
\pm \\
- \\
- \\
= \\
\pm \\
= \\
- \\
- \\
+ \\
+ \\
+ \\
- \\
+ \\
+ \\
+ \\
+\end{array}$ & $\begin{array}{l}4 \\
2 \\
3 \\
1 \\
3 \\
3 \\
3 \\
6 \\
5 \\
4 \\
2 \\
2 \\
2 \\
1 \\
1 \\
1 \\
3 \\
3 \\
3 \\
2 \\
5 \\
2 \\
5 \\
4 \\
1 \\
4 \\
2 \\
2 \\
2\end{array}$ \\
\hline $\begin{array}{l}\text { Internal defects } \\
\text { Cardiovascular } \\
\text { Congenital heart disease } \\
\text { Urogenital } \\
\text { Cystic dysplasia of kidney } \\
\text { Hydronephrosis } \\
\text { Unicornuate uterus } \\
\text { Hypoplasia of ovaries } \\
\text { Leydig cell hyperplasia of teste: } \\
\text { Alimentary } \\
\text { Universal mesentery } \\
\text { Atresia of bile-ducts } \\
\text { CNS } \\
\text { Porencephaly } \\
\text { Endocrine } \\
\text { Pituitary hypoplasia } \\
\text { Adrenal hypoplasia } \\
\text { Other abnormalites } \\
\text { Mental retardation } \\
\text { Physical retardation } \\
\text { Retarded ossification } \\
\text { Hemiatrophy } \\
\text { Hypotonia } \\
\text { Lipomatosis of limbs } \\
\text { Hydatidiform change of } \\
\text { placentis }\end{array}$ & + & + & + & + & + & & + & + & $\begin{array}{l}+ \\
+ \\
\pm \\
\pm \\
\pm \\
+ \\
- \\
- \\
+ \\
+ \\
? \\
+ \\
+ \\
\pm \\
+ \\
-\end{array}$ & $\begin{array}{l}1 \\
2 \\
1 \\
1 \\
1 \\
1 \\
1 \\
1 \\
1 \\
1 \\
1 \\
3 \\
3 \\
2 \\
2 \\
2 \\
1 \\
1\end{array}$ \\
\hline
\end{tabular}

Gestation (wk.)

Birthweight (kg.)

Placenta weight (kg.)

\section{Age examined \\ Maternal age (yr.) \\ Number of abortions \\ Age at death}

normalities

Abnormal shape of skull

Abnormal palpebral fissures

rolds

igh arched palate

Flexion deformity of fingers

ndactyly of hands

Abnormal dermatoglyph

alipes, equinovarus

Congenital heart diseas

Universal mesentery Atresia of bile-duct

Pituitary hypoplasia

Adrenal hypoplasia form change of placent:3 
are phenotypic males without signs of intersexuality. This variability of the developmental abnormalities in triploids coupled with the intersexuality in the males suggests some imbalance between the activity of the sex chromosome complement and the three autosome sets. This is borne by sex chromatin analysis. With some exceptions (Mittwoch and Delhanty, 1961; Mittwoch, Atkin, and Ellis, 1963), XXY triploids are chromatin negative (Boué, Boué, and Lazar, 1967) while the majority of chromatin positive nuclei in XXX triploids have only a single chromatin mass. In the present case only $2.5 \%$ of the nuclei contained two chromatin bodies, which is a much smaller proportion than would be expected in 47,XXX females. Schmid and Vischer (1967) confirmed by autoradiography the presence of a single allocycloic (late replicating) $\mathrm{X}$ in their 71, XXXYY cell line.

Edwards et al. (1967) have reviewed the origins and frequency of triploidy in man referring extensively to the work of Beatty (1957), Austin (1960), and Carr (1965). This does not need further elaboration here except to make the comment that the disproportionately high frequency of the 69,XXY karyotype among reported triploids compared with $69, \mathrm{XXX}$ and especially $69, \mathrm{XYY}$ may not be due to differences in the frequency of diandry and digyny but to relative survival rates of the affected zygotes. Indeed Boue et al. (1967) and J. G. Boué and A. Boué (1968, personal communication) have shown that cells from $69, \mathrm{XYY}$ tissue grow so poorly in culture that attempts to produce suitable material for karyotype analysis could often fail. Only the study of more specimens will elucidate this point.

It seems possible that the haemolytic process observed in our child was caused by ABO incompatibility, though a positive direct Coombs test using standard methods is unusual in this condition, and the level of anti-A found post partum in the mother's serum was less than usually associated with haemolytic disease. No antibodies were found in the mother's serum against other blood group antigens, and no other cause was found, either clinically or at necropsy for the rapid rise in serum bilirubin. The child's ABO genotype may have been AAO indicating dispermy. If this were so an increased amount of antigen A may have been present on the infant's cells, though its influence in the development of ABO inccmpatible haemolytic disease must at present remain a matter of conjecture. However it is of interest that there was also evidence of a haemolytic process caused by ABO incompatibility in the mosaic triploid described by Lejeune et al. (1967).

\section{Summary}

A premature female who survived only 23 hours is described. External anomalies included hyper $-\stackrel{\mathbb{D}}{\rightarrow}$ telorism, bilateral microphthalmia, and colobomata low-set ears, single palmar creases, absent flexionos creases of some fingers, and unusual dermato-o glyphs. Internal defects included congenital hearto disease (atrial and ventricular septal defects, bicus- $\overline{\bar{c}}$ pid aortic and pulmonary valves), cystic hypo- $-\overline{0}$ plasia of kidney and hydronephrosis, hypoplasia of ovaries, pituitary, and adrenals. Haemolytic diseases was possibly due to $\mathrm{ABO}$ incompatibility.

Chromosome analysis of blood and skin re- $\vec{\omega}$ vealed complete triploidy $(69, \mathrm{XXX})$. Studies of nuclear areas confirmed the presence of a single cell population in fibroblast cultures, and only $2.5 \%$ of nuclei were observed with two sex chromatin bodies.

The congenital malformations of other complete $\vec{\omega}$ and mosaic triploids reported are tabulated and은 discussed. Reference is made to the imbalance between the sex chromosome complement and the autosomes resulting in intersexuality shown by $69, \mathrm{XXY}$ males.

We would like to thank Dr. A. D. M. Jackson for per- $\vec{\bullet}$ mission to study this child and Dr. K. L. G. Goldsmigh o for the analysis of the maternal anti-A globulin. We awe also grateful to Mrs. Elaine Butler for estimating the nuclear areas, to Mrs. F. M. Byron, Miss V. Clark, afor Miss $\mathrm{H}$. Thurston for technical assistance, and to Miss I. K. Haverly for her secretarial help.

\section{REFERENCES}

Austin, C. R. (1960). Anomalies of fertilization leading to triploidy. F. cell comp. Physiol., 56, Suppl. 1, p. 1 .

Beatty, R. A. (1957). Parthenogenesis and Polyploidy in Mammalia Development. Cambridge University Press, Cambridge.

Bernard, R., Stahl, A., Coignet, J., Giraud, F., Hartung, M., Brusquet, Y., and Passeron, P. (1967). Triploïdie chromosomique chez un nouveau-né polymalformé. Ann. Génét., 10, 70.

Böök, J. A., and Santesson, B. (1960). Malformation syndrome in man associated with triploidy (69 chromosomes). Lancet, 1, 858. , and - (1961). Nuclear sex in triploid XXY human cells. ibid., 2, 318.

Boué, J. G., Boué, A., and Lazar, P. (1967). Les aberrations chromosomiques dans les avortments. Ann. Génét., 10, 179.

Carr, D. H. (1965). Chromosome studies in spontaneous abortions. 윽 Obstet. and Gynaec., 26, 308.

Chantler, C., Baum, J. D., and Norman, D. A. (1967). Dextrostix in the diagnosis of neonatal hypoglycaemia. Lancet, 2, 1395.

Edwards, J. H., Yuncken, C., Rushton, D. I., Richards, S., and Mittwoch, U. (1967). Three cases of triploidy in Man. Cyto- O genetics, 6,81 .

Ellis, J. R., Marshall, R., Normand, I. C. S., and Penrose, L. S. (1963). A girl with triploid cells. Nature (Lond.), 198, 411.

Ferrier, P., Ferrier, S., Stalder, G., Bühler, E., Bamatter, F., and Klein, D. (1964). Congenital asymmetry associated with diploidtriploid mosaicism and large satellites. Lancet, 1, 80.

Keith, C. G. (1966). The ocular manifestations of trisomy 13-15. Trans. ophthal. Soc. U.K., 86, 435.

Lejeune, J., Salmon, Ch., Berger, R., Réthoré, M. O., Rossier, A. and Job, J. C. (1967). Chimère 46,XX/69,XXY. Ann. Génét., $10,188$. 
Mittwoch, U., Atkin, N. B., and Ellis, J. R. (1963). Barr bodies in triploid cells. Cytogenetics, 2, 323.

-, and Delhanty, J. D. A. (1961). Nuclear sex in triploid XXY human cells. Lancet, $2,552$.

Penrose, L. S. (1968). Dermatoglyphs in human polyploidy. $f$. med. Genet., $5,1$.

Sacrez, R., Clavert, J., Willard, D., Rumpler, Y., M’Bede, J., Meyer, R., and Korn, R. (1967). La triploidie chez l'enfant. Pédiatrie, 22, 267.
Schmid, W., and Vischer, D. (1967). A malformed boy with double aneuploidy and diploid-triploid mosaicism 48,XXY/71, XXXYY. Cytogenetics, 6, 145.

Snodgrass, G. J. A. I., Butler, L. J., France, N. E., Crome, L., and Russell, A. (1966). The ' $D$ ' (13-15) trisomy syndrome: an analysis of 7 examples. Arch. Dis. Chi'dh., 41, 250.

World Health Organization (1966). Standardization of procedures for chromosome studies in abortion. Bull. Wld Hlth Org., 34, 765. 